(c) Group of authors, 2021

UDC 616-006.446.8

DOI - https://doi.org/10.14300/mnnc.2021.16038

ISSN - 2073-8137

\title{
CYTOLOGICAL ASSESSMENT OF MARGINAL GINGIVAL EPITHELIUM IN RECESSION
}

\author{
Gusarina E. I. ${ }^{1}$, Borodulina I. I. ${ }^{2}$, Grebnev G. A. ${ }^{2}$, \\ Grigoryevskaya E. A. ${ }^{2}$, Grigoryevsky D. I. ${ }^{2}$, Sirak S. V. ${ }^{3}$, Lenev V. N. ${ }^{3}$ \\ ${ }^{1}$ MEDI, Saint Petersburg, Russian Federation \\ ${ }^{2}$ S. M. Kirov Military Medical Academy, Saint Petersburg, Russian Federation \\ ${ }^{3}$ Stavropol State Medical University, Russian Federation
}

\section{ЦИТОАОГИЧЕСКАЯ ОЦЕНКА ЭПИТЕАИЯ МАРГИНААЬНОЙ АЕСНЫ ПРИ РЕЦЕССИИ}

\author{
Е. И. Гусарина ${ }^{1}$, И. И. Бородулина ${ }^{2}$, Г. А. Гребнев ${ }^{2}$, \\ Е. А. Григорьевская ${ }^{2}$, А. И. Григорьевский ${ }^{2}$, С. В. Сирак ${ }^{3}$, В. Н. Аенёв $^{3}$ \\ 1 МЕАИ, Санкт-Петербург, Российская ФеАерация \\ 2 Военно-меАицинская акалемия им. С. М. Кирова, Санкт-Петербург, \\ Российская ФеАерация \\ ${ }^{3}$ Ставропольский госуАарственный меАицинский университет, \\ Российская ФеАерация
}

In patients with recession, cytological examination of the marginal gingiva in the area of the affected teeth reveals bacterial cocci-infested epithelial cells, dystrophic altered epithelial cells, and segmented white blood cells. We examined patients with recession who underwent plastic surgery to create tissue attached to the previously exposed roots. The surgery used a coronally-displaced flap and a connective tissue graft from the palate. Three months after the surgery, the inflammation of the marginal gingival epithelium had disappeared, and signs of proliferation and differentiation of epithelial cells were observed.

Keywords: gingival epithelium, recession, surgical management of gingival recession

У пациентов с рецессиями при цитологическом исследовании маргинальной десны в области пораженных зубов до операции определяются бактериально обсемененные кокками клетки эпителия, дистрофически измененные эпителиоциты, сегментоядерные лейкоциты. Через три месяца после оперативного формирования прикрепленных тканей в области ранее оголенных корней путем пластики рецессий коронально-смещенным лоскутом с применением соединительно-тканного трансплантата явления воспаления в эпителии краевой десны купируются, появляются признаки пролиферации и дифференцировки клеток эпителия.

Ключевые слова: эпителий краевой десны, рецессия десны, пластика рецессий

For citation: Gusarina E. I., Borodulina I. I., Grebnev G. A., Grigoryevskaya E. A., Grigoryevsky D. I., Sirak S. V., Lenev V. N. CYTOLOGICAL ASSESSMENT OF MARGINAL GINGIVAL EPITHELIUM IN RECESSION. Medical News of North Caucasus. 2021;16(2):169-172. DOI - https://doi.org/10.14300/mnnc.2021.16038

Для цитирования: Гусарина Е. И., Бородулина И. И., Гребнев Г. А., Григорьевская Е. А., Григорьевский Д. И., СИрак С. В., Ленёв В. Н. ЦИТОЛОГИЧЕСКАЯ ОЦЕНКА ЭПИТЕЛИЯ МАРГИНАЛЬНОЙ ДЕСНЫ ПРИ РЕЦЕССИИ. МеДИцинский вестник Северного Кавказа. 2021;16(2):169-172. DOI - https://doi.org/10.14300/mnnc.2021.16038

OM - oral mucosa

T

he oral mucosa is highly resistant to various stimuli and is characterized by a high capacity for regeneration as a result of its structure [1, 2]. The high probability of damage in this area dictates special conditions for personalized programs of care for the oral mucosa. Such programs should be based on a knowledge of the causes, conditions, and mechanisms of damage and protection [3, 4]. A typical reason for the disrupted function of the oral mucosa, accompanied by inflammatory phenomena, is poor oral hygiene. Thus, inflammation of the marginal gingiva around teeth with recession, caused by accumulation of soft plaque on the surface of the exposed root of the tooth and trauma during brushing, leads to impairment of the barrier function of the oral mucosa $[5,6]$.

Surgical intervention to restore the gingiva to the level of the cemento-enamel junction allows the integrity of the protective barrier to be restored and full oral hygiene to be achieved. The implementation of complex postoperative 
rehabilitation measures should be based on the results of fundamental and applied studies with a functional and morphological assessment of the oral mucosa [7, 8]. Understanding the mechanism of these changes ensures the effectiveness of such pathogenetic approaches [9, 10].

The aim of this study was to investigate the morphological state of the epithelium of the marginal gingiva around teeth with recession before and after plastic surgery.

Material and Methods. The study group included 12 patients: 6 men (with 14 teeth with recession) and 6 women (with 15 teeth with recession) aged 26 to 63 years, who were scheduled for surgical treatment. The recession was localized to the anterior teeth of the lower jaw and belonged to Miller classes I and II. All the subjects were assessed as satisfactory (from 0.7 to 1.6 ) on the OHI-S hygiene index. According to clinical and radiological data, the patients had no signs of generalized periodontitis.

Samples were collected by scraping the gingival epithelium in the area of recession with a sterile trowel. The material was applied to a non-greased slide, distributed evenly in a thin layer, dried at room temperature, then fixed in $96 \%$ ethyl alcohol for 10 minutes and stained with hematoxylin-eosin. The prepared material was examined using a Zeiss Axiolmager A2 microscope (Göttingen, Germany) at magnifications of $\times 50, \times 100, \times 200, \times 400$, and $\times 600$. and photographs were taken using the Zen program (Germany).

The smears were used to study quantitative and qualitative changes in cells that characterize the inflammatory process, using parameters such as the presence of a large number of segmented leukocytes and basophilic masses (tissue detritus, exfoliated dead epithelial scales with microorganisms), microorganisms including intracellular cocci and bacilli, dystrophic changes (vacuolization of nuclei and cytoplasm, changes in the color of nuclei and cytoplasm, changes in the size and shape of nuclei, karyolysis phenomena, karyorexis, and karyopyknosis), destructive changes in cells, proliferative cell activity, and a decrease in the signs of dystrophy (restoration of the normal cell structure, the presence of basal cells with nuclei, a decrease in basophilic masses and epithelium). X-cells (cells with signs of necrobiosis) were detected. The number of cells in five visual fields was estimated. The obtained data were averaged by obtaining a sample average value, and entered into a table for analysis.

Patients underwent plastic surgery in the area of recession with a coronally-displaced flap using a connective tissue graft according to the modified method of Zucchelli and De Sanctis [11].

Under local infiltration anesthesia (Sol. Ultracaini DC 1.7 $\mathrm{ml}$ ) in the area of recession, a modified oblique incision was made, preserving the interdental papillae, with the intragroove part of the incision located in the area of recession and the paramarginal part located in the projection of the papillae. The incision was extended mesially and distally to the adjacent tooth on each side. A split muco-periosteal flap was raised with sufficient mobilization. The root surface was treated mechanically and chemically using periodontal curettes (Hu-Friedy, Germany) and Prefgel ( $\mathrm{pH}$-neutral root surface conditioner with 24\% EDTA content; Straumann, Switzerland). The vestibular surface of the gingival papillae was de-epithelialized.

A subepithelial graft taken from the palatal area adjacent to teeth 4-6 was applied to the prepared root surface and fixed with vertical mattress sutures at the base of the interdental papillae. The graft was covered with the mobilized flap and fixed with simple and wrapped sutures using Prolen (Ethicon, Johnson \& Johnson, USA) 6.0; 7.0 suture material.
After 3 months, a second cytomorphological examination of a scraping from the newly formed gum epithelium in the same area was performed.

Statistical analysis of the obtained data was performed using the Statistica 10.0 (StatSoft, USA) software package using the methods of variation statistics. The initial data and the results 3 months after treatment were compared using the Wilcoxon paired test. A $p$ value $<0.05$ was considered statistically significant.

Results and Discussion. Our cytological study in a group of patients before and 3 months after surgical intervention revealed statistically significant improvements in indicators $(p<0.05)$. The data confirmed the clinical picture in the oral cavity. Before the operation, the marginal gingiva in the area of recession was often loose, hyperemic, with the remains of soft plaque, and was cytologically accompanied by the presence of basal and parabasal cells. Cells with bacterial contamination with cocci $(27 \pm 6.8)$ were identified, indicating a change in the microbiocenosis. Dystrophic altered epithelial cells appeared $(26 \pm 4.1)$. We noted the presence of segmented white blood cells that «attacked» epithelial cells and led to their destruction. The described cytopathological changes are a manifestation of inflammation of the marginal epithelium.

After surgical treatment, decreases were observed in the number of cells with basophilic stained cytoplasm (from $41 \pm 5.3$ to $12 \pm 2.3$ ), the total number of epithelial cells (from $231 \pm 37.9$ to $64 \pm 9.1$ ), the number of cells with dystrophic changes (from $26 \pm 4.1$ to $11 \pm 1.8$ ), the number of cells with signs of phagocytosis (from $18 \pm 3.2$ to $3 \pm 0.6$ ), the number of epithelial cells with flora (from $27 \pm 6.8$ to $3 \pm 0.5$ ), and the number of neutrophilic leukocytes (from $216 \pm 39.5$ to $28 \pm 4.9)(p<0.05)$.

There was evidence of proliferation and differentiation of epithelial cells, but there were no basal or parabasal cells. Individual white blood cells and monocytes were located mainly outside the squamous epithelial cells. An increased number of cells were of different degrees of maturity and differentiation, which indicated activation of the proliferative process of cells in this area after the plastic surgery (Table).

Cytological examination of the marginal gingiva with recession (number of cells)

\begin{tabular}{|c|c|c|c|}
\hline Parameters & $\begin{array}{l}\text { Before } \\
\text { treatment }\end{array}$ & $\begin{array}{c}\text { After } \\
\text { treatment }\end{array}$ & $p^{*}$ \\
\hline Total epithelium & $231 \pm 37.9$ & $64 \pm 9.1$ & 0.0002 \\
\hline $\begin{array}{l}\text { Epithelium with } \\
\text { cytoplasmic } \\
\text { basophilia }\end{array}$ & $41 \pm 5.3$ & $12 \pm 2.3$ & 0.009 \\
\hline $\begin{array}{l}\text { Epithelium } \\
\text { with dystrophic } \\
\text { changes }\end{array}$ & $26 \pm 4.1$ & $11 \pm 1.8$ & 0.01 \\
\hline $\begin{array}{l}\text { Epithelium } \\
\text { with signs of } \\
\text { phagocytosis }\end{array}$ & $18 \pm 3.2$ & $3 \pm 0.6$ & 0.01 \\
\hline X-cells & $8 \pm 1.6$ & $4 \pm 0.7$ & 0.05 \\
\hline $\begin{array}{l}\text { Nuclear-free } \\
\text { epithelial cells }\end{array}$ & $3 \pm 0.5$ & 0 & 0.007 \\
\hline $\begin{array}{l}\text { Epithelium with } \\
\text { flora }\end{array}$ & $27 \pm 6.8$ & $3 \pm 0.5$ & 0.04 \\
\hline Neutrophils & $216 \pm 39.5$ & $28 \pm 4.9$ & 0.02 \\
\hline $\begin{array}{l}\text { Bare-nucleus } \\
\text { leukocytes }\end{array}$ & $32 \pm 7.1$ & $4 \pm 0.9$ & 0.04 \\
\hline
\end{tabular}

* Statistically significant differences were proved with a probability of the null hypothesis of less than $5 \%(p<0.05)$. 
The proliferation of epithelial cells is characteristic of the active process of exfoliation and is a sign of destruction in the marginal epithelium during gingival recession (231 \pm 37.9 ). After plastic surgery, the number of epithelial cells decreased by a factor of $4(64 \pm 9.1)$, which characterized the active regeneration of the marginal epithelium $(p<0.0002)$.

During inflammation, the integrity of epithelial cells with normal eosinophilic cytoplasm was disrupted. The oxidation process resulting from cell damage caused the cytoplasm to become basophilic. According to the cytomorphological study, the number of cells with cytoplasmic basophilia decreased from $41 \pm 5.3$ cells before the plastic surgery to $12 \pm 2.3(p<0.009) 3$ months after the surgery.

Signs of epithelial cell dystrophy include vacuolization; changes in the color, size, and shape of the nuclei and cytoplasm; and the phenomena of karyolysis, karyorexis, and karyopyknosis. When comparing the data obtained before and after surgical treatment, the number of cells with dystrophic changes decreased by a factor of 2 from $26 \pm 4.1$ to $11 \pm 1.8(p<0.01)$ (Fig.)
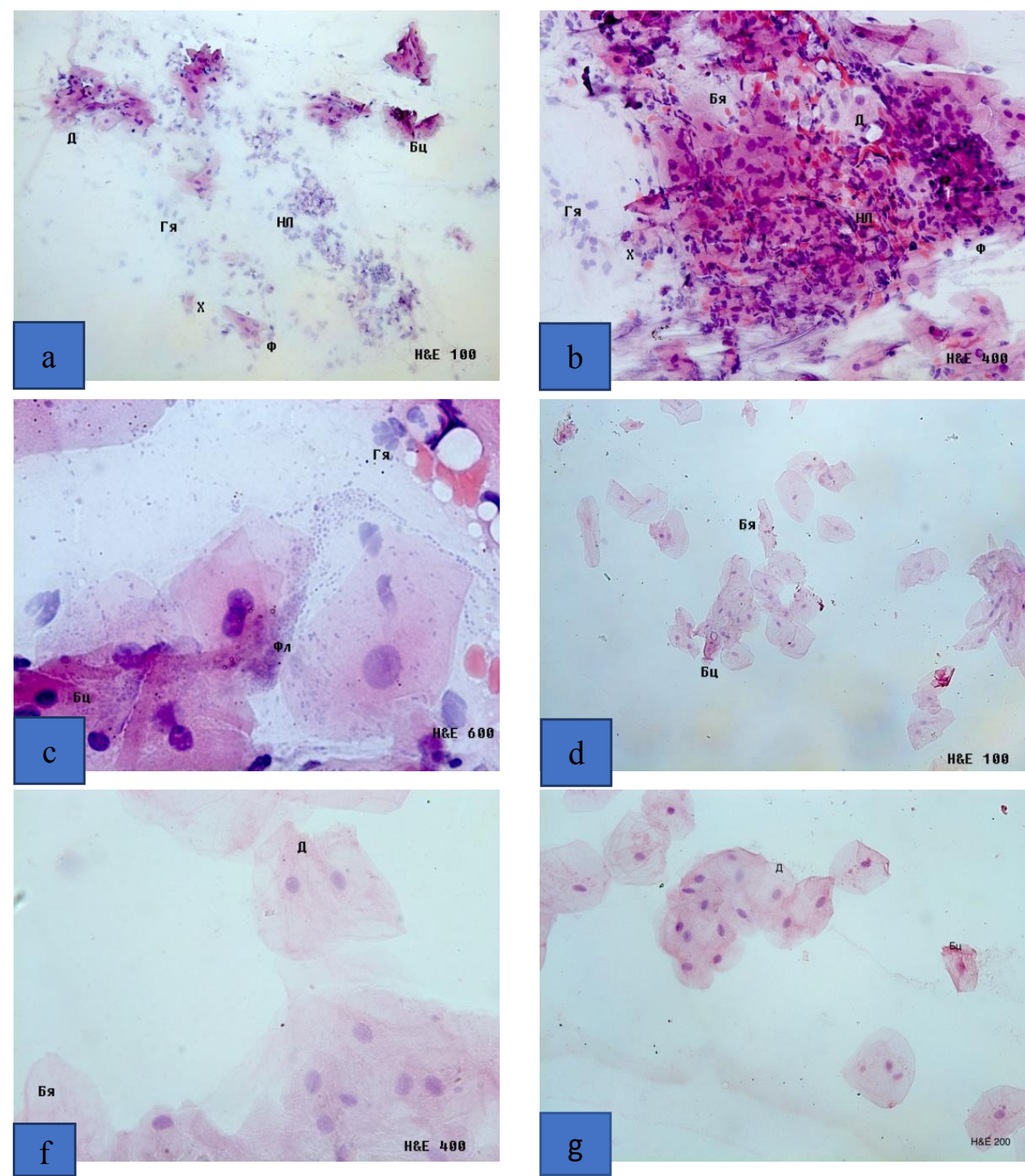

Fig. Cytology of the epithelium of the marginal gingiva in a 48-year-old patient. Hematoxylin-eosin staining: a) before treatment $\times 100$; b) before treatment $\times 400$; C) before treatment $\times 600$; d) after treatment $\times 100$; f) after treatment $\times 400$; g) after treatment $\times 200$. $\mathrm{D}$ - epithelial dystrophy; $\mathrm{Cb}$ - cytoplasmic basophilia; $\mathrm{Ne}$ - non-nuclear epithelial cells;

$\mathrm{BI}$ - bare-nucleus leukocytes; $\mathrm{N}$ - neutrophils; $\mathrm{X}$ - X-cells; Ef - epithelium with flora
The active inflammatory process is characterized by «phaging» epithelial cells - cells with signs of phagocytosis and the presence of neutrophilic leukocytes in the cytoplasm. The number of cells with signs of phagocytosis in the epithelium at the edge of the recession area was had decreased 6 -fold to $3 \pm 0.6(p<0.05)$, which indicated a

Cells in the stage of necrobiosis (X-cells), which received their name because of the inability to identify them, indicate active inflammation. After the plastic surgery to treat recession, their number decreased by a tor of 2 from $8 \pm 1.6$ to $4 \pm 0.7(p<0.05)$ in the marginal epithelium of the gingiva $(\mathrm{p}<0.007)$

Epithelial cells containing cocci and bacillus microorganisms at the edge of the areas of recession numbered $27 \pm 6.8$. At 3 months after the plastic surgery, their numbers reduced by a factor of 9 to $3 \pm 0.5$ $(p<0.04)$.

Large numbers of neutrophilic leukocytes characterize the active inflammatory process. The plastic surgery treatment reduced their number by a factor of 8 , from $216 \pm 39.5$ to $28 \pm 4.9 \quad(p<0.02)$. The activity of the inflammatory process confirms the presence of bare-nucleus white blood cells in a state of cytolysis. The plastic surgery treatment also reduced the number of bare-nucleus white blood cells by a factor of 8 to $4 \pm 0.9(p<0.04)$.

Conclusions. Gingival recession allows the accumulation of plaque because of the difficulty of performing high-quality oral hygiene, and results in inflammation of the marginal gingival epithelium. These changes are qualitatively and quantitatively confirmed by the results of cytological examination of the marginal gingival mucosa in the area of recession, indicating the ongoing processes of dystrophy, increased desquamation, and the death of epithelial cells. These phenomena lead to progressive loss of the marginal gingiva and deepening of the recession.

The attachment of tissue in the area of previously exposed roots by performing plastic surgery 
with a coronally-displaced flap and a connective tissue graft relieves the inflammation of the marginal gingiva, which is confirmed by cytomorphological changes. The conditions created for gingival repair allow the patient to conduct high-quality oral hygiene with the use of local remedies that stimulate sanogenetic mechanisms.
Informed consent. When conducting the study, we were guided by the ethical principles of the Helsinki Declaration and the «Rules of Good Clinical Practice in the Russian Federation". The study was performed with the informed consent of the patients and was approved by the Ethics Committee (protocol No. 194 of 19.09.2017).

Disclosures: The authors declare no conflict of interest.

Acknowledgements. We thank Helen Jeays, BDSc AE, from Edanz (www.edanz.com/ac) for editing a draft of this manuscript.

\section{References}

1. Chen Y., Guan Q., Han X., Bai D., Li D., Tian Y. Proteoglycans in the periodontium: A review with emphasis on specific distributions, functions, and potential applications. Journal of Periodontal Research. 2021:00:1-16. https://doi.org/10.1111/jre.12847

2. Vitkov L., Minnich B., Knopf J., Schauer C., Hannig M. [et al.] NETs Are Double-Edged Swords with the Potential to Aggravate or Resolve Periodontal Inflammation. Cells. 2020;9(12):2614. https://doi.org/10.3390/cells9122614

3. Kinane D. F., Stathopoulou P. G., Papapanou P. N. Periodontal diseases. Nature reviews. Disease primers. 2017;3:17038. https://doi.org/10.1038/nrdp.2017.38

4. Petersen P. E., Ogawa H. Strengthening the prevention of periodontal disease: the WHO approach. Journal of Periodontology. 2005;76(12):2187-93

https://doi.org/10.1902/jop.2005.76.12.2187

5. Hennequin-Hoenderdos N. L., Slot D. E., Van der Weijden G. A. The incidence of complications associated with lip and/or tongue piercings: a systematic review. International Journal of Dental Hygiene. 2016;14(1):62-73. https://doi.org/10.1111/idh.12118

6. Akhremenko Y. A., Cheremkina A. S., Tarasova L. A. Ushnitsky I. D. Microbiocenosis in inflammatory processes of marginal gum among children. Wiadomości lekarskie. 2015;68(4):493-5

7. Kassab M. M., Cohen R. E. The etiology and prevalence of gingival recession. Journal of the American Dental Association. 2003;134(2):220-5.

https://doi.org/10.14219/jada.archive.2003.0137

8. Zucchelli G., Mounssif I. Periodontal plastic surgery. Periodontology 2000. 2015;68(1):333-68. https://doi.org/10.1111/prd.12059

9. Baker P. Gingival Recession - Causes and Management. Primary Dental Journal. 2020;8(4):40-47. https://doi.org/10.1308/205016820828463843

10. Sirak S. V., Shchetinin E. V., Bykova N. I., Petrosyan G. G., Tarabrina A. G. [et al.] The histochemical features of the endothelium of the tooth-alveolar complex in inflammation and osteoporosis. Medical News of North Caucasus. 2018;13(3):520-525.

https://doi.org/10.14300/mnnc.2018.13095

11. Zucchelli G., De Sanctis M. Treatment of multiple recession-type defects in patients with esthetic demands. Journal of Periodontology. 2000;71(9):1506-1514. https://doi.org/10.1902/jop.2000.71.9.1506

\section{About authors:}

Gusarina Elena Ivanovna, Chief Physician;

tel.: +79219954212; e-mail: gussarina@gmail.com

Borodulina Irina Ivanovna, MD, DMSc, Associate Professor, Professor of the Department

of maxillofacial surgery and surgical dentistry;

tel.: +79602598162; e-mail: borodulina59@mail.ru

Grebnev Gennady Aleksandrovich, MD, DMSc, Professor, Head of the Department

of maxillofacial surgery and surgical dentistry;

tel.:+79213926551; e-mail: grebnev06@rambler.ru

Grigoryevskaya Elena Arkadievna, Head of the Clinical Laboratory of the Central Pathology Laboratory; tel.: +79216751540; e-mail: pmo-cpal@mail.ru

Grigoryevsky Dmitry Igorevich, pathologist of the pathomorphological

Department of the Central Pathoanatomic Laboratory;

tel.: +79817054675; e-mail: pmo-cpal@mail.ru

Sirak Sergey Vladimirovich, MD, DMSc, Professor, Head of the Department of dentistry;

tel.: +78652350551; e-mail: sergejsirak@yandex.ru; https://orcid.org/0000-0002-4924-5792

Lenev Vadim Nikolaevich, MD, CMSc, Associate Professor of the Department of dentistry, tel.: +78652350551; e-mail: lenevstom@yandex.ru 